\title{
ConvergênCIA ENTRE BIOLOGIA EVOLUTIVA E CIÊNCIAS SOCIAIS
}

\author{
Geraldo Pedro da COSTA FILHO*
}

RESUMO: O artigo tem como objetivo fazer uma retrospectiva das tentativas de aproximação entre a biologia evolutiva e as ciências sociais, identificando os obstáculos que surgiram no começo da consolidação da biologia e da sociologia como ciências, no século XIX, e as afinidades entre elas que foram se revelando por meio de conceitos como organismo e evolução, desenvolvidos ao longo do século XX pela sociologia e a biologia.

PALAVRAS-CHAVE: Biologia evolutiva. Sociologia. Evolução. Darwin.

Este artigo é o resultado de pesquisas que foram realizadas no decorrer do exercício do magistério superior, como professor de sociologia e antropologia na Universidade Federal do Piauí. Como costuma acontecer com docentes dos departamentos de Ciências Sociais das universidades brasileiras, ministrei disciplinas em outros cursos que preveem Sociologia ou Antropologia nos currículos. Para todos me preparei com uma preocupação: elaborar programas que tivessem a maior afinidade com as respectivas áreas.

Isso se devia à observação da prática docente dos professores e dos relatos sobre experiências letivas com outros cursos, que revelavam desinteresse dos alunos com os conteúdos de sociologia e antropologia, normalmente resultando em baixo rendimento de aprendizagem, fato que se consubstancia em uma pergunta corrente entre alunos: "Mas, para que serve essa sociologia e antropologia?"

Com o objetivo de buscar afinidades entre as ciências sociais e as áreas do conhecimento que demandavam por sociologia e antropologia, percebi a ausência de

\footnotetext{
* UFPI - Universidade Federal do Piauí. Departamento de Ciências Sociais e Educação. Parnaíba PI - Brasil.64202-020 - gpcf65@gmail.com. https://orcid.org/0000-0002-8355-7757.
} 
algo que começou a chamar a atenção. No curso de ciências sociais da Universidade Federal do Ceará, nos anos de 1980, o interesse pelo que na época se denominava antropologia física foi despertado por disciplinas que abordavam a origem e a evolução do homem. Não obstante a ênfase na antropologia cultural, livros e textos que tratavam esse tema - ou sob a perspectiva evolucionista ou sob o ponto de vista difusionista ${ }^{1}$ - inevitavelmente faziam referência à teoria da evolução de Charles Darwin. A partir de então, passei a considerar o conhecimento da teoria da evolução darwiniana como de importância relevante para a formação acadêmica do profissional de Ciências Sociais, porém, não somente para esse profissional, mas para todos aqueles que se graduam em cursos que têm como objetivo o estudo do comportamento do homem.

Todavia, como professor universitário, comecei a observar que a importância que se concedia às teorias darwinianas, não era compartilhada por colegas de profissão. Percebi, como resultado da experiência de lecionar em vários cursos, que nada havia nas ementas das disciplinas de ciências sociais desses cursos que indicasse a presença das teorias evolucionistas. Essa ausência me surpreendeu.

A princípio, isto levou a duas conclusões: ou os sociólogos e antropólogos que elaboraram as ementas não tiveram na formação universitária - licenciatura ou bacharelado - contato com o estudo da teoria da evolução; ou, se tiveram, deram pouca atenção a esse conteúdo - o que não deixa de ser uma postura válida, pois podem ter considerado a teoria da evolução das espécies insustentável cientificamente.

As duas conclusões encontram sustentação. Porém, ao procurar verificar a consistência para a segunda conclusão me deparei com uma verdadeira guerra contra as tentativas de aproximação entre as teorias darwinianas - sustentadas sobre cinco teses: a evolução dos seres, a ancestralidade comum, o gradualismo evolutivo, a especiação (cladogênese) ${ }^{2}$ e a seleção natural e sexual - e as ciências sociais.

Melhor seria dizer tentativas de reaproximação entre estas áreas, pois como salientou Barberis (2004), no nascimento da sociologia, segunda metade do século XIX, ela sofreu forte influência das ideias evolucionistas de Darwin que começaram a se propagar após a publicação de $A$ origem das espécies, em 1859. Durante esse contexto, que se caracterizou pela preponderância da explicação culturalista

\footnotetext{
1 Segundo os evolucionistas as culturas se desenvolvem de maneira uniforme e linear, de modo que deve se esperar que cada sociedade percorra as etapas já ultrapassadas pelas sociedades consideradas "avançadas". (LARAIA, 1997) Para os difusionistas, era fundamental a relação histórica entre as culturas, o que os levava a estudar a distribuição geográfica e a migração de traços culturais, postulando que culturas eram mosaicos de traços com várias origens e histórias; para eles, a história cultural era uma narrativa fragmentada de encontros culturais, migrações e influências, cada instância da qual era única (FERREIRA, 2012).

2 Cladogênese: processo evolutivo que leva à diversificação de espécies (ramificação) ao longo de uma mesma árvore filogenética (MAYR, 2009).
} 
sobre tendências naturalistas, houve, no último quarto do século XIX, tentativas de desenvolver uma sociologia sobre bases biológicas, especialmente na França. Segundo Barberis (2004):

As teorias previamente existentes e dominantes que davam conta do comportamento gregário humano, interpretavam os grupos humanos como sendo produto da decisão e reflexão, em outras palavras, como grupos "artificiais". Deste ponto de vista, os seres humanos teriam começado a viver juntos porque encontraram utilidade e benefício nestes agrupamentos: a sociedade seria um expediente encontrado pela razão para melhorar as condições de existência humana. (BARBERIS, 2004, p. 132).

A sociologia que ficou conhecida por organicista, foi uma reação àquelas explicações dominantes, que apoiada nos conhecimentos biológicos da época se preocupava com a construção de uma base científica mais sólida para a sociologia nascente, principalmente na França, em que na posição oposta se encontrava Durkheim:

A sociologia organicista, em resposta a este gênero de teorias do mundo social, defendia que a sociedade era um produto natural, como uma planta ou um animal; ela nascia, crescia, e se desenvolvia por virtude de uma necessidade interna. (...) Esta linha de argumentação se baseava na crença em um contínuo entre os fenômenos naturais, entre os quais existiam apenas diferenças de grau, mas não saltos qualitativos. (...) A continuidade da natureza tinha, como consequência lógica, a unidade da ciência: o conhecimento destes fenômenos naturais contínuos constituía um contínuo epistemológico paralelo, de forma que todas as ciências formavam parte de um único espectro. (BARBERIS, 2004, p. 132).

No início do século XX, a sociologia organicista - sob forte crítica dos adeptos da teoria durkheimiana - retrocedeu. As principais acusações convergiam para a impossibilidade de se fazer analogias entre o funcionamento do organismo vivo e a sociedade, consequência do pressuposto epistemológico da teoria de Durkheim (1982), exposto em As regras do método sociológico, que preconizava que a explicação para um fato social se encontrava em outro fato social. Por outro lado, Barberis (2004) assinalou a forte influência do organicismo na sociologia que se institucionalizou na França, berço da disciplina:

(...) eu gostaria de enfatizar que várias das suposições do organicismo permaneceram como parte da sociologia que teve êxito em institucionalizar-se academicamente na França, isto é, como parte da sociologia durkheimiana. Durkheim 
partilhou várias das preocupações do organicismo: ele também desejava estabelecer a realidade da sociedade, sua complexidade, o fato que ela era uma entidade natural, e a possibilidade do estudo científico desta entidade. (BARBERIS, 2004, p. 135).

A resistência explícita à aproximação entre a biologia e as ciências sociais tem origem no contexto de suas institucionalizações como ciências, principalmente pelo lado dos cientistas sociais. Essa atitude refratária de sociólogos e antropólogos à aproximação com a biologia caracterizará a relação entre estas áreas ao longo de todo o século XX, ora com maior ora com menor intensidade.

Para Soares (2009), é possível compreender a atitude de Durkheim - ao estabelecer ferreamente o pressuposto epistemológico que deveria orientar a construção da explicação sociológica - como uma tentativa de demarcar território, definindo os limites entre as áreas de atuação das ciências, particularmente em relação à psicologia, que tal qual à sociologia também começara a se desenvolver e se institucionalizar no final do século XIX.

No entanto, parece que mesmo em As regras do método sociológico, de 1895, Durkheim (1982) deixou antever uma ontologia do ser social na qual as expressões da consciência individual merecem consideração sociológica, concepção que, a meu ver, posteriormente foi desenvolvida, mesmo inconfessadamente, com a elaboração do conceito de anomia. Vejam como ele encontrou dificuldades para eliminar do objeto de estudo das ciências sociais as manifestações das consciências individuais:

As manifestações privadas têm realmente algo de social também, uma vez que reproduzem em parte um modelo coletivo; mas cada uma delas depende outrossim, e em larga parte, da constituição orgânico-psíquica do indivíduo, das circunstâncias particulares em que está colocado. Não constituem, pois, fenômenos propriamente sociológicos. Estão presas aos dois reinos ao mesmo tempo; poderíamos chamá-las de sociopsíquicas. Interessam ao sociólogo, sem constituir matéria imediata da sociologia. Do mesmo modo, encontramos mesmo no interior do organismo fenômenos de natureza mista, estudados por ciências mistas como a química biológica. (DURKHEIM, 1982, p. 7).

A dependência que, segundo Durkheim (1982), em larga parte as manifestações privadas, que reproduzem modelos coletivos (instituições sociais), têm em relação à constituição orgânico-psíquica do indivíduo me chamou a atenção para a possibilidade de que a sua sociologia - sem reconhecer explicitamente contemplasse também como objeto de estudo as manifestações individuais, ainda que sem ser prioridade. Mesmo que ele continuasse a professar que essa relação interessa 
ao sociólogo apenas secundariamente, pois ela não seria a matéria prioritária do saber sociológico, sou obrigado a discordar do seu pressuposto epistemológico fundamental. Os conhecimentos desenvolvidos, no final do século XX e na primeira década do XXI, pela biologia evolutiva e a neurociência, sobre a estrutura genética do homem e as funções do cérebro, e sua influência sobre o comportamento social apontam para a necessidade do cientista social reavaliar seu interesse sobre esses fenômenos mistos.

É compreensível a atitude refratária contra a aproximação com a biologia por parte das ciências sociais como consequência de influência remota, porém persistente, que também remete ao contexto histórico de formação da sociologia e da antropologia no século XIX. Trata-se da leitura unilateral da concepção de adaptação individual e social do homem de Herbert Spencer (2016), que segundo os críticos justificava teses racistas (eugenia) propugnadas pelo darwinismo social.

É importante relembrar que uma das teses sobre as quais se fundamenta a teoria da evolução de Darwin $(2004,2013)$ é a seleção natural e sexual, que favorece a adaptação evolutiva, no sentido de que os indivíduos que apresentam características mais aptas para se adaptar a um determinado contexto ambiental encontram maiores probabilidades de sucesso do que aqueles que não as possuem. A teoria não defende que a adaptação evolutiva seleciona e favorece os mais fortes, embora a força física, em certas situações, possa ser considerada uma característica evolutiva funcional. A leitura que vinculou aptidão evolutiva à força física, transmutada em poderio econômico e militar, distorcendo a teoria de Darwin (2004, 2013), foi feita pelo darwinismo social.

Darwin $(2004,2013)$, diferente da suposta interpretação que Herbert Spencer (2016) teria realizado de sua teoria, desde o início vinculou a seleção natural à indeterminação da aleatoriedade das mutações e à dependência das condições ambientais, que, no caso dos humanos, é o conjunto formado pela modelagem cultural das sociedades. De acordo com Stélio Marras (2010):

Selvagem [natural] ou doméstica [cultural], a "seleção natural" compreende ambas e supõe a indeterminação. Tal lente transformista nos leva para longe de uma noção reificada, essencialista, estável ou sempiterna de natureza. Mais longe ainda de uma noção naturalista de sociedade, assim transplantada das ciências naturais às sociais, e tão divulgada por tantos dos chamados darwinistas sociais. Neste sentido, Herbert Spencer fez muito mal à compreensão de Charles Darwin, afastando-o cada vez mais das ciências sociais modernas. (MARRAS, 2010, p. 10).

Spencer foi ungido como o santo padroeiro do darwinismo social. Sem sombra de dúvida sua obra embasou o evolucionismo inglês e posteriormente americano 
que, em conjunto com o organicismo francês, influenciaram as ciências sociais no nascedouro. Porém, uma leitura mais matizada (contextualizada) e menos ideológica de Spencer permite a possibilidade de vê-lo como um intelectual de gabinete mais sofisticado do que sua mera classificação como um truculento darwinista social.

De acordo com Kardiner e Preble (1964):

Há um conflito fundamental na obra de Spencer que ele não parece fazer a menor tentativa para resolver: de um lado, a sua crença na necessidade de progresso no processo evolutivo e, de outro, a compreensão de que as condições locais afeiçoam os padrões adaptativos que favorecem a evolução em qualquer ambiente. A primeira convicção foi muito mais divulgada do que a segunda, graças em parte, às dramáticas deduções que dela sacou Spencer e, em parte, graças à sua utilidade em servir aos interesses particulares dos seus críticos. (KARDINER e PREBLE, 1964, p. 50).

Spencer (2016) demonstrava conhecer mais a obra de Darwin do que poderiam imaginar os críticos, sua ideia de adaptação do homem e da sociedade às condições do meio não significava necessariamente adaptação e evolução progressivas. As características ambientais influenciavam e modelavam esse processo, podendo inclusive provocar paralisação ou retrocesso:

Spencer insistiu também em que as condições imediatas de um meio determinam o curso de evolução nesse meio. A menos de haver em andamento uma evolução universal progressiva de condições, entre as quais se incluiriam as de clima e terreno, por exemplo, a evolução social não implica necessariamente em progresso. Em seus Princípios de Sociologia afirma-o com muita clareza: "Figura-se comumente a evolução como se em tudo subentendesse uma intrínseca propensão de elevar-se; mas é errônea a concepção. A evolução é sempre determinada pela cooperação de fatores internos e externos." A despeito dessas passagens, a maior parte dos críticos se contenta em apresentá-lo como um advogado incompetente da evolução "progressiva". (KARDINER e PREBLE, 1964, p. 51).

Portanto, se o comportamento rebelde à aproximação com a evolução darwiniana procura legitimar sua posição se apropriando da ortodoxia epistemológica de Durkheim (1982), buscando resguardar para os fatos sociais o privilégio de possuir as causas explicativas para os fatos sociais, desconsiderando as manifestações das consciências individuais; ou, com o mesmo objetivo, apropriando-se da crítica seletiva e unilateral que persiste há mais de um século feita contra Spencer, que lhe imputa o ônus da responsabilidade pelo darwinismo social, acredito que tais obje- 
tivos estão na contramão de uma leitura mais contextualizada e menos ideológica da obra destes autores.

Nem Émile Durkheim (1982) se fecha totalmente às manifestações das consciências individuais, fato que se comprova com o aparecimento do conceito de anomia, que é por onde se delineiam os caminhos que levam à mudança social, consequência de dificuldades de adaptação ${ }^{3}$ dos indivíduos às instituições sociais que são expressas pela consciência coletiva de um momento histórico; nem Herbert Spencer era um simples defensor e propagador da expansão territorial e marítima do Império Britânico, cuja obra deveria justificar cientificamente uma epopeia de conquistas.

Com efeito, a convergência esteve em estado latente (estase) durante décadas, tendendo a aflorar em alguns momentos, tornando-se mais explícita ao chegar o final do século XX, na década de 1990, denominada como a década do cérebro. Barberis (2004) apontou o estado de latência no qual hibernou a aproximação entre biologia evolutiva e ciências sociais, com alguns momentos de interrupção, ainda que com a roupagem organicista:

O organicismo ajudou a estabelecer a realidade da sociedade como objeto, e a possibilidade de seu estudo científico. A metáfora orgânica permaneceu na sociologia posterior de forma não explícita, porém continuou a estar presente. Poderíamos dizer que ela sofreu um processo de "repressão" e que como todo conteúdo "reprimido" ela se manifesta de formas das quais não temos consciência. (BARBERIS, 2004, p. 136).

Para ilustrar esse movimento de aproximação que permanecia em estase, as interfaces entre natureza e cultura, ou melhor, biologia evolutiva e ciências sociais - que haviam sido reprimidas após os primeiros lampejos organicistas e mesmo darwinista social - voltaram a aparecer, como fantasmas inconscientes, nas ciências sociais contemporâneas, seja como contribuições para a compreensão do comportamento social produzidas pela biologia evolutiva, neurociência, sociobiologia ou psicologia evolutiva seja por meio das próprias ciências sociais, como demonstrou Stélio Marras (2010):

(...) nas ciências sociais contemporâneas, principalmente em seu acento simétrico, nas comutações entre sujeito e objeto, na recusa em separar humanos de nãohumanos, sob o epíteto de natural ou social, na atenção para os infinitos modos de composição da realidade, eis que podemos retomar, sem o pejo anterior,

\footnotetext{
3 É interessante frisar essas dificuldades de adaptação dos indivíduos às instituições sociais, comprovando que as preocupações de Spencer - que escreveu antes de Durkheim - quanto à adaptação do homem e da sociedade não eram sem cabimento.
} 
o naturalismo construtivista ou transformista, assim dizendo, de Darwin. (MARRAS, 2010, p. 10).

Exemplo significativo é o de Tim Ingold (1992) que sugeriu que não há separação cognitiva entre natureza e sociedade, sendo esta cisão uma característica da percepção da cultura ocidental. Ao estudar grupos caçadores/coletores modernos, concluiu:

Para eles não existem dois mundos, o das pessoas (a sociedade) e o das coisas (a natureza), mas apenas um mundo - um ambiente - saturado de poderes naturais e abrangendo tanto os seres humanos como os animais e plantas dos quais dependem, e a paisagem em que vivem e se movimentam. (INGOLD, 1992, p. 42).

No livro Estar vivo (2015), publicado originariamente em 2011, Ingold propôs o que ficou conhecido como uma antropologia imersa na vida. Na verdade, o relato de um diálogo permanente com a biologia e a psicologia evolutiva, cujo objetivo é direcionar a antropologia para o conhecimento dos fluxos e percursos da vida no mundo, quer dizer, para conhecer e descrever a história dos seres humanos e não humanos no mundo.

Em termos epistemológicos, trata-se de um empreendimento que procura desfazer as fronteiras estabelecidas entre cultura e biologia, ciências humanas e naturais, ciências especulativas e empíricas. De acordo com Steil e Carvalho (2012):

Ao postular uma teoria do conhecimento que se funda sobre o engajamento e a simetria entre todos os seres que habitam o mundo, Ingold abala um dos pilares do humanismo científico ocidental, que estabelece o distanciamento e a externalidade do pesquisador em relação ao seu objeto como condição primeira para a produção de um conhecimento objetivo e universalmente válido. Esta posição, como se pode ver na leitura de seus escritos tem profundas consequências epistemológicas e ontológicas. (STEIL e CARVALHO, 2012, p. 9-10).

A antropologia de Tim Ingold (1992), portanto, faz parte do projeto de construção de uma antropologia simétrica, como assinalou Marras (2010) tal como a antropologia de Bruno Latour (1994), com o seu paradigmático Jamais fomos modernos: ensaio de antropologia simétrica. Ambos, por caminhos diversos, convergem para aproximar os seres humanos não só dos animais, mas também das pedras, dos mares, dos céus, dos ventos, dos solos, das marés. Com efeito: 
Se a antropologia social desafiava o pesquisador a "ver o mundo desde o ponto de vista do nativo", tomado como um ser humano, partícipe de outra cultura, diferente da sua, a proposta de Ingold (...) desafia-o a experimentar o mundo desde o lugar de cada um dos seres materiais que condensam e atualizam a vida em diferenciadas e múltiplas formas que compõem o ambiente físico, estético e sensorial que o envolve. (STEIL e CARVALHO, 2012, p. 10-11).

No entanto, a obra que inaugurou essa tendência do final do século XX foi $O$ enigma do homem, com o subtítulo "Para uma nova antropologia" de Edgar Morin, publicada em 1975. Na Introdução de $O$ enigma, o autor relembrou que a motivação que o conduziu para uma teoria que conciliasse biologia evolutiva e ciências sociais remetia à juventude, quando questões existenciais normalmente afloram e é comum se interrogar sobre: Quem somos nós? ou O que é o homem no mundo? Explicou como elas foram reprimidas para só posteriormente voltarem com força capaz de lançá-lo em um programa de pesquisa que se constituiu em desafio:

A orientação teórica é nova para mim, mas a preocupação é primordial. No meu livro L'homme et la mort, escrito em 1948-50, procurei estabelecer o ponto de união e de ruptura entre a biologia e a ciência do homem (...).

Creio (...) que eu me formulava uma daquelas perguntas ingênuas, banais, evidentes, que todos formulam entre os 7 e os 17 anos de idade e que são inibidas, recalcadas, asfixiadas, ridicularizadas logo que entramos nas Universidades e nas Doutrinas. Autodidata por temperamento, isto é, não deixando me intimidar demasiado pelos decretos da Escola e a majestade das Autoridades espirituais, não conseguia impedir-me de considerar o nó górdio que a antropologia oficial pensava ter cortado magnificamente. Como se sabe, a teoria reinante do homem fundamenta-se não só na separação, mas também na oposição entre as noções de homem e de animal, de cultura e de natureza, com tudo o que não está conforme a este paradigma sendo condenado como "biologismo", "naturalismo", "evolucionismo".

Agora, depois de me ter outorgado um atestado de suficiência, devo culpar-me por ter, depois disso, durante quase vinte anos, deixado adormecer em mim a pergunta fundamental. É bem verdade que jamais pude considerar o homem uma entidade fechada, separada, radicalmente alheia à natureza, e que, quando (...) me pergunto de novo "Quem somos nós? O que é o homem no mundo?", procuro formular uma "antropocosmologia". (MORIN, 1975, p. 11-12).

Entretanto, faltava-lhe conhecimento biológico e em áreas afins que pudesse lhe dar sustentação científica para a empreitada pretendida, fato que com honestidade e humildade intelectual incomum reconheceu: 
Sem me dar conta do que fazia, encerrei-me no pequeno gueto das ciências humanas e, no momento em que me aproximo mais do problema central, ainda me encontro mais longe dele em virtude das limitações de meus conhecimentos e da mesquinhez de minha cultura. Na minha Introduction à une politique de l'homme, escrita na mesma época, o problema bioantropológico surge repetidas vezes, mas de modo estourado, fragmentado, superficial, ignorante (...).

Assim minha preocupação biológica tornava-se nebulosa, mitológica, e teria continuado a degradar-se, sem dúvida, se os abalos de 1968 não tivessem, por caminhos semi-aleatórios, despertado e alimentado minhas primeiras interrogações [da juventude]. (MORIN, 1975, p. 12).

Dois acontecimentos, a partir de 1968, foram apontados como cruciais para o que denominou não sua conversão à biologia, mas sim sua reconversão teórica. O primeiro foi a participação em um grupo de debates formado por biólogos e cientistas ligados à cibernética, no qual descobriu que a cibernética ${ }^{4}$ longe de ser uma redução simplista à esquemas mecanicistas, constituía, ao contrário, numa introdução à complexidade. O segundo, e decisivo acontecimento, foi o convite para o Salk Intitute for Biological Studies.

Segundo ele, ${ }^{5}$ admitimos, desde Darwin, que somos filhos de primatas, mas não que nós próprios somos primatas. Estamos convencidos de que, descendo da árvore genealógica tropical, na qual vivia nosso antepassado comum, escapamos dela para sempre, com o fim de construirmos para nós, fora da natureza, o reino independente da cultura.

Contudo, concluiu Morin (1975), essa dualidade antitética homem/animal, cultura/natureza se chocava com a realidade: é evidente que o homem não é constituído por duas fatias sobrepostas, uma bionatural e a outra psicossocial; é evidente que ele não é atravessado por um muro separando a parte humana da parte animal; é evidente que cada homem é uma totalidade biopsicossociológica.

No entanto, de acordo com Morin (1975), a biologia pelo menos a praticada até os anos de 1950, a da síntese dos anos de 1930 e 1940 ou segunda revolução darwiniana, sofria limitações para fornecer à ciência do homem um quadro de referência, ou melhor, os meios para a ligação bioantropológica, pois a vida era concebida como uma qualidade original própria aos organismos, sem interações fundamentais com outra ordem de fenômenos. Como consequência, a biologia

\footnotetext{
4 Ciência que tem como objeto o estudo comparativo dos sistemas e mecanismos de controle automático, regulação e comunicação nos seres vivos e nas máquinas. Segundo Norbert Wiener (1968), do ponto de vista da transmissão da informação, a distinção entre máquinas e seres vivos, humanos ou não, é mera questão de semântica.

5 Todas as menções comentadas feitas a Edgar Morin no decorrer da exposição de sua teoria ao longo do capítulo referem-se ao livro O enigma do homem: para uma nova antropologia (1975).
} 
se fechava ao universo físico-químico dos átomos e das moléculas, ao qual se negava deixar reduzir; e também se fechava ao universo social, que embora muito disseminado no reino animal, não era assimilado por falta de conceitos adequados. A biologia, portanto, estava fechada para todas as qualidades ou faculdades que ultrapassavam estritamente a fisiologia, isto é, para tudo aquilo que nos seres vivos é comunicação, conhecimento e inteligência:

Assim, a biologia estava encerrada no biologismo, ou seja, uma concepção de vida fechada no organismo, tal como a antropologia no antropologismo, ou seja, uma concepção insular do homem. Ambas pareciam concernidas por uma substância própria, original. (MORIN, 1975, p. 23).

A mudança começou pouco antes de 1950. Segundo ele, foram abertas brechas no âmbito de cada paradigma fechado, brechas que eram, ao mesmo tempo, aberturas para os outros campos até então proibidos e através das quais se operaram as primeiras conexões para novas emergências teóricas. Wiener, em 1948, com a cibernética e logo após Shannon, em 1949, com a teoria da informação, abriram uma nova perspectiva teórica aplicável, ao mesmo tempo, às maquinas artificiais, aos organismos biológicos, aos fenômenos psicológicos e sociológicos.

O primeiro ato da revolução biológica, portanto, tratava-se da abertura da biologia para baixo, isto é, para as estruturas físico-químicas. Contudo, poucos perceberam que a abertura para baixo era, ao mesmo tempo, para cima, constituindo o segundo ato da revolução biológica:

Na verdade, a nova biologia não reconduzia apenas a vida celular a seus substratos nucleoproteinados [abertura para baixo]. ${ }^{6}$

(...) a nova biologia teve de recorrer a princípios de organização desconhecidos em química, isto é, à noção de informação, de código, de mensagem, de programa, de comunicação, de inibição, de repressão, de expressão, de controle [abertura para cima]. Estas noções têm todas um caráter cibernético, no sentido que identificam a célula com uma máquina autocomandada e controlada informacionalmente. A aplicação à célula, ou seja, à unidade fundamental de vida, da noção de máquina já constituía por si própria um acontecimento primordial. (...) tratava-se de um verdadeiro salto epistemológico (...). Isto é, sem dúvida, o que há de surpreendente nesta abertura para "cima": informação, código, mensagem, programa, comunicação, inibição, repressão, etc. são conceitos extraídos da experiência das relações humanas e pareciam, até então inseparáveis da complexidade

\footnotetext{
6 Proteínas conjugadas com ácidos nucleicos que ocorrem no núcleo das células e são essenciais para a divisão celular e a reprodução. Os ácidos nucleicos são as biomoléculas mais importantes do controle celular, pois contêm a informação genética.
} 
psicossocial. Não era extraordinário que pudessem ser aplicados a máquinas artificiais, já que, afinal de contas, o controle, o comando e o programa eram produzidos e fabricados pelo homem, sendo integrado nas suas relações sociais. O extraordinário era conceber esta alta organização na fonte da própria vida, como se a célula fosse uma sociedade complexa de moléculas regida por um governo. (MORIN, 1975, p. 25-26).

Com a compreensão da célula, da máquina e da sociedade sob a perspectiva dos princípios organizacionais surgiu a questão da tendência para à complexificação crescente, que se traduziu pela dinâmica entre entropia (desorganização, desestruturação) e neguentropia (reorganização, reestruturação). Tratava-se do paradoxo da organização viva, cuja ordem informacional que se forma ao longo do tempo parece contradizer um princípio de desordem (entropia) que se difunde no tempo; este paradoxo só pode ser enfrentado a partir de uma concepção que liga estreitamente ordem e desordem, que faz da vida um sistema de reorganização (neguentropia) permanente fundado sobre uma lógica da complexidade.

Para John von Neumann (apud MORIN, 1975) a complexidade era uma noção-chave. Significava que a máquina natural coloca em jogo um número de unidades e de interações infinitamente maior do que a máquina artificial, como também significava que o ser vivo está sujeito a uma lógica de funcionamento e desenvolvimento diferente, uma lógica na qual intervêm a indeterminação, a desordem e o acaso como fatores de organização superior ou de auto-organização. Essa lógica do vivo é, sem dúvida, mais complexa do que aquela que nosso entendimento aplica às coisas.

Em uma sociedade, existem sempre forças de desordem em ação, que não são apenas entropias individuais (envelhecimento e morte), mas entropias propriamente sociais, decorrentes das eventualidades individuais que a sociedade deve reabsorver e dos antagonismos organizacionais inerentes à sua complexidade. A desordem (comportamentos aleatórios, competições, conflitos) é ambígua: é, por um lado, um dos constituintes da ordem social (diversidade, variedade, flexibilidade, complexidade), mas por outro lado, permanece ao mesmo tempo, desordem, ou seja, ameaça de desintegração. A ameaça permanente mantida pela desordem é aquilo que dá a sociedade seu caráter complexo e vivo de reorganização permanente:

Radicalmente diferente da ordem mecânica, a ordem "viva" é aquela que renasce sem cessar. Com efeito, a desordem é sem cessar ou esponjada pela organização, ou recuperada e metamorfoseada no seu contrário (hierarquia), ou expelida para fora (desvio) e mantida na periferia (faixas marginais de jovens). Sem cessar esponjada, expelida, rejeitada, recuperada, metamorfoseada, a desordem renasce 
sem cessar. E eis onde aparece a lógica, o segredo, o mistério da complexidade ${ }^{7}$ e o sentido profundo do termo auto-organização: uma sociedade autoproduz-se pelo fato de se autodestruir sem cessar. (MORIN 1975, p. 47).

Assim, concluiu Morin (1975, p. 28-29), os conhecimentos produzidos pelas teorias da informação, da cibernética e dos sistemas abertos forneceram subsídios para superar o biologismo e o antropologismo, abrindo caminho para um novo programa de pesquisa em construção: “(...) a "revolução biológica” foi apenas iniciada. O velho paradigma está desfeito em migalhas, o novo ainda não está constituído. Mas a noção de vida já se modificou: está, implícita ou explicitamente, ligada às ideias de auto-organização e de complexidade."

Onde se via o homo sapiens saltando da natureza e produzindo, com sua inteligência, a técnica, a linguagem, a sociedade, a cultura se testemunha agora, o contrário, a natureza, a sociedade, a inteligência, a técnica, a linguagem e a cultura co-produzindo o homo sapiens, ao longo de um processo que durou alguns milhões de anos - o conceito de coevolução gene-cultura que Wilson (2013) trabalhou anos depois estava bem fundamentado em Edgar Morin (1975).

Há um fio condutor de análise que perpassa toda morfogênese complexa e multidimensional que preside a evolução humana: o desenvolvimento do cérebro.

Uma tal complexidade desanima de início e seria tentador querer procurar um fio condutor. Isso não significa, de modo algum, convém repetir, que desejemos reduzir a hominização ao desenvolvimento cerebral; significa, sim, que ligaremos o desenvolvimento cerebral a todos os outros, aqueles que o desenvolvimento cerebral provoca, mas também aqueles que o provocam. Salientemos: o cérebro, aqui, não é considerado um órgão, mas sim o epicentro daquilo que é, para nós, o essencial da hominização: um processo de complexificação multidimensional, em função de um princípio de auto-organização ou autoprodução. (MORIN, 1975, p. 62).

Edgar Morin (1975) revelou o caminho para a interface entre ciências sociais, a biologia evolutiva e a neurociência. Partindo de autores compartilhados com essas ciências, antecipou programa de pesquisa que ainda continua um desafio para a sociologia e a antropologia.

\footnotetext{
7 Para Morin (1975, p. 120): “(...) este paradoxo se esclarece se considerarmos a organização do sistema vivo um processo de autoprodução permanente ou autopoiesis (MATURANA, 1972) ou de reorganização permanente (TRINCHER, 1965; ATLAN, 1972), o qual reabsorve, expulsa a entropia que se produz continuamente no interior do sistema e responde aos atentados desorganizadores vindos do meio ambiente."
} 
Assim, o processo de cerebralização é ontogenético (isto é, a complexificação sociocultural impele ao uso pleno das aptidões cerebrais) e filogenético (isto é, as mutações que produzem novas aptidões começarão a ser exploradas pela complexificação sociocultural).

Os progressos da cerebralização são inseparáveis dos da juvenilização. Esta corresponde a um abrandamento ontogenético, isto é, à prolongação do período biológico de infância e da adolescência e até mesmo a um inacabamento ontogenético, ou seja, ao inacabamento da substituição das características juvenis pelas adultas. A prolongação da infância permite a continuação do desenvolvimento organizacional do cérebro em relação estreita e complementar com os stimulli do mundo exterior e incitações culturais, o que significa que a lentidão do desenvolvimento ontogenético é favorável à aptidão para aprender, ao desenvolvimento intelectual, à impregnação e, portanto, à transmissão cultural. (MORIN, 1975, p. 87).

O prolongamento da infância está ligado de modo multidimensional à sociedade, o que permite integrar as estruturas socioculturais fundamentais nos cérebros e as estruturas fundamentais dos cérebros nas estruturas socioculturais, favorecendo o desenvolvimento tanto intelectual quanto afetivo do indivíduo.

Da mesma forma, o adulto é inacabado cerebralmente no sentido em que o cérebro pode continuar a aprender, alcançar novas adaptações, adquirir novas estratégias, novos conhecimentos depois do período da infância e da juventude. A juvenilização da espécie é uma juvenilização cerebral, isto é, a potencialidade de uma inteligência e de uma sensibilidade jovem no adulto e até mesmo no velho.

A juvenilização também corresponde à persistência de certa afetividade infantil, primeiramente, no adolescente e, depois, no adulto. Além disso, já se desenvolviam nos indivíduos, antes do sapiens, a emotividade e uma sensibilidade cada vez maiores, uma aptidão maior para sofrer, bem como para serem invadidos por fobias, repulsões, aversões que conduziriam ao ódio e, por fim, a capacidade de amar, fonte de fraternidade, de ímpetos, de adoração, de dedicação, de piedade.

Com efeito, à semelhança de Piaget (2003), quando este analisou a evolução cognitiva do cérebro, Morin (1975), ao descrever o progresso da juvenilização, concluiu que ele significou a regressão dos comportamentos estereotipados (instintuais) que eram programados de modo inato, a abertura extrema ao meioambiente (natural e social), a aquisição de uma plasticidade e disponibilidade muito amplas. Também concluiu que o progresso da cerebralização correspondeu ao desenvolvimento das possibilidades associativas do cérebro, à constituição de estruturas organizacionais ou competências, não só linguísticas, como também operacionalmente lógicas, heurísticas e inventivas. E, por último, que o progresso da culturalização correspondeu à multiplicação das informações, dos conhecimentos, 
do saber social e, também, à multiplicação das regras de organização e dos modelos de comportamento:

Por outras palavras, a cultura insere-se complementarmente na regressão dos instintos (programas genéticos) e na progressão das competências organizacionais, reforçada simultaneamente por essa regressão (juvenilizante) e por essa progressão (cerebralizante), necessária a esta e àquela. Ela constitui um "tape-recorder", um capital organizacional, uma matriz informacional, apta a alimentar as competências cerebrais, a orientar as estratégias heurísticas, a programar os comportamentos sociais. (MORIN, 1975, p. 91).

Finalmente, segundo Morin (1975), apareceu o rosto biossociocultural da hominização. As estruturas de organização cognitivas, linguísticas, práticas, que emergiram com os novos desenvolvimentos do cérebro são estruturas inatas que substituíram os programas estereotipados ou instintos, que foram, a partir de então, inscritas na herança genética, enquanto desta, foi subtraído ou recalcado grande número de comportamentos estereotipados. Mas elas só podem ser operacionalizadas a partir da educação sociocultural - que nada mais é do que o sentido lato do conceito de socialização. É a integração da natureza com a cultura, o que Ridley (2013), três décadas depois, chamou de a expressão dos genes (portanto, da natureza) por meio da cultura.

Aqui resolve-se um dos paradoxos que opunha de modo estéril o papel do inato e o do adquirido no homem. Aquilo que se elabora no decorrer do período de hominização é a aptidão inata para adquirir e é o dispositivo cultural de integração do adquirido. Mais ainda: é a aptidão natural para a cultura e a aptidão cultural para desenvolver a natureza humana.

Já não podemos mais escapar à ideia de uma complementaridade original entre a aquisição dessas aptidões naturais (as competências organizacionais inatas) e a existência da cultura. Com efeito, partindo de certa etapa, a complexidade do cérebro e a complexidade sociocultural só podem encaixar-se uma na outra e, por conseguinte, os desenvolvimentos últimos das forças generativas do cérebro só podem exprimir-se com base numa complexidade fenomenal sociocultural. (MORIN, 1975, p. 92).

Para Morin (1975), estava perfeitamente claro que o grande cérebro do homo sapiens só pode ter surgido, ser bem sucedido e triunfar, depois da formação de uma cultura já complexa. Ele se surpreendeu que se tenha, durante muito tempo, acreditado exatamente no contrário, que o sapiens deu origem à cultura. ${ }^{8}$

\footnotetext{
8 Na verdade, até chegar ao sapiens, a cultura foi elaborada progressivamente, por milhares de anos, pelos antepassados que remetem à árvore evolutiva da família homínida e do gênero homo. (MITHEN, 2002)
} 
Segundo ele, não são apenas os inícios da hominização, mas seu acabamento, que se tornam incompreensíveis se desassociarmos evolução biológica e evolução cultural como sendo dois cursos distintos. Sua associação mostra, por um lado, que o papel da evolução biológica é muito maior do que se pensava no processo social e na elaboração cultural, mas, por outro lado, também se constata que o papel da cultura, que ainda recentemente era insuspeitado, é capital para a continuação da evolução biológica até o sapiens. Assim, o antigo paradigma que opunha natureza e cultura desmoronou.

Na conclusão de $O$ enigma, escrita com estilo dramático, Edgar Morin (1975) lançou a ponte definitiva que deve superar a oposição natureza/cultura, ressaltando a necessidade de as ciências sociais acompanharem as pesquisas sobre a evolução do cérebro, portanto, uma ponte com a neurociência:

Os sinos dobram por uma antropologia reduzida a uma tênue faixa psicocultural flutuando como um tapete voador sobre o universo natural. Os sinos dobram por uma antropologia que não teve o sentido da complexidade, embora seu objeto seja o mais complexo de todos e que se assustava com o menor contato com a biologia, a qual, com objetos menos complexos, se baseia em princípios de conhecimento mais complexos.

Os sinos dobram por uma teoria fechada, fragmentada e simplificante do homem. A era da teoria aberta, multidimensional e complexa já começa.

A antropologia fundamental deve rejeitar toda e qualquer definição que faça do homem uma entidade, seja supra-animal (...) seja estritamente animal (...); ela deve reconhecer o homem como ser vivo para distingui-lo dos outros vivos, ela deve ultrapassar a alternativa ontológica natureza/cultura. (MORIN, 1975, p. 199).

Até recentemente - Morin escreveu em 1973 - a antropologia excluía do seu campo não só o sistema genético (a física-química) e o ecossistema (vida-natureza), mas também o cérebro. No entanto, não se pode mais ignorar a inter-relação genético-cultural. Não é apenas o desenvolvimento biológico do cérebro que é indispensável para compreender a formação da cultura; é, também, o desenvolvimento cultural que é indispensável para conceber o desenvolvimento biológico do cérebro até o homo sapiens.

A partir do sapiens, a evolução genética foi freada e modificada pela exogamia e continuou, cada vez mais, pelos grandes caldeamentos de população nas sociedades históricas. A diáspora da espécie foi acompanhada por modificações genéticas menores, deixando intacto o caráter primordial universal: a natureza hipercomplexa do cérebro sapiental. As diferenças étnicas, por exemplo, são diferenças genéticoculturais nas quais a cultura intervém, não só de maneira seletiva com respeito a certos genótipos, mas também de modo co-formativo com respeito aos fenótipos. 
Enfim, a cultura coopera, combinando sua própria herança com a hereditariedade biológica, o que, por vezes, inibe e, outras vezes, estimula o aparecimento das diferenças singulares de indivíduo para indivíduo.

O fenômeno principal, portanto, não é o desaparecimento da natureza na cultura por milagre de espiritualização, mas sim uma integração de uma na outra. Esta proposição geral significa, entre outras coisas, que toda e qualquer unidade de comportamento humano é, ao mesmo tempo: genética/cerebral/social/cultural/ ecossistêmica (o que não impede, segundo as necessidades dos estudos específicos, de enfatizar este ou aquele aspecto em detrimento dos outros - Morin (1975) relembrava os domínios de pesquisa específicos de cada disciplina científica). Significa, igualmente, que o fundamento da ciência do homem é policêntrico; o homem não tem uma essência específica que seja somente genética ou somente cultural, sua natureza está na inter-relação, na interação, na interferência neste e por este policentrismo.

\section{THE CONVERGENCE BETWEEN EVOLUTIONARY BIOLOGY AND SOCIAL SCIENCES}

ABSTRACT: This article's aims are to retrace the attempts to bring evolutionary biology closer to the social sciences by identifying the obstacles that arose at the beginning of the consolidation of biology and sociology as sciences in the nineteenth century and the affinities between them, revealed through concepts such as organism and evolution, developed throughout the twentieth century by both sociology and biology.

KEYWORDS: Evolutionary biology. Sociology. Evolution. Darwin.

\section{CoNvergencia ENTRE BIOLOGÍA EVOLUTIVA Y CIENCIAS SOCIALES}

RESUMEN: El artículo tiene como objetivo hacer una retrospectiva de los intentos de aproximación entre la biología evolutiva y las ciencias sociales, identificando los obstáculos que surgieron al comienzo de la consolidación de la biología y de la sociología como ciencias en el siglo XIX, y las afinidades entre ellas, que se fueron revelando por intermedio de conceptos como organismo y evolución, desarrollados a lo largo del siglo XX por la sociología y la biología.

PALABRAS CLAVE: Biología evolutiva. Sociología. Evolución. Darwin. 


\section{REFERÊNCIAS}

BARBERIS, Daniela S. O organismo como modelo para a sociedade: a emergência e a queda da sociologia organicista. In: R.A. Martins; L.A.C.P. Martins; C.C. Silva; J.M.H. Ferreira (orgs.) Filosofia e história da ciência no Cone Sul: $3^{\circ}$ Encontro. Campinas: AFHIC, p. $131-136,2004$.

DARWIN, Charles. A origem das espécies. Rio de Janeiro: Ediouro, 2004.

A expressão das emoções no homem e nos animais. São Paulo: Companhia das Letras, 2013.

DURKHEIM, Emile. As regras do método sociológico. 10 ed. São Paulo: Ed. Nacional, 1982.

FERREIRA, Flávio Rodrigo Freire. A "morte" da cultura? Do modelo clássico ao debate contemporâneo. Revista Inter-legere, n. 14, p. 132-148, 2012.

INGOLD, Tim. Comment on "Beyond the original affluent society" by N. Bird-David. Current Anthropology. Chicago, v. 33, p. 34-47, 1992.

. Estar vivo. Petrópolis: Vozes, 2015.

KARDINER, Abram e PREBLE, Edward. Eles estudaram o homem: vida e obra dos grandes antropologistas. São Paulo: Editora Cultrix, 1964.

LARAIA, Roque de Barros. Cultura: um conceito antropológico. 11 ed. Rio de Janeiro: Jorge Zahar Editora, 1997.

LATOUR, Bruno. Jamais fomos modernos: ensaio de antropologia simétrica. São Paulo: Editora 34, 1994.

MARRAS, Stélio. Natureza darwiniana, domesticação científica e pensamento moderno. Revista Brasileira de Ciência, Tecnologia e Sociedade, v.1, n. 2, p. 3-35, 2010.

MAYR, Ernst. O que é a evolução. Rio de Janeiro: Rocco, 2009.

MITHEN, Steven. A pré-história da mente: uma busca das origens da arte, da religião e da ciência. São Paulo: Editora da UNESP, 2002.

MORIN, Edgar. O enigma do homem: para uma nova antropologia. Rio de Janeiro: Zahar Editores, 1975.

PIAGET, Jean. Biologia e conhecimento. 4 ed. Petrópolis: Vozes, 2003.

RIDLEY, Matt. O que nos faz humanos: genes, natureza e experiência. 3 ed. Rio de Janeiro: Record, 2013. 
SOARES, Alisson Magalhães. Sociologia e sociobiologia: autonomia vs. (socio) biologização da sociologia. 2009. 178f. Dissertação (Mestrado em Sociologia) - Programa de Pós-Graduação em Sociologia e Antropologia, Universidade Federal de Minas Gerais, Belo Horizonte, 2009.

SPENCER, Herbert. Primeiros princípios. São Paulo: Editora Ex Machina, 2016.

STEIL, Carlos Alberto e CARVALHO, Isabel Cristina de Moura. Cultura, percepção e ambiente: diálogos com Tim Ingold. São Paulo: Editora Terceiro Nome, 2012.

WIENER, Norbert. Cibernética e sociedade: o uso humano de seres humanos. São Paulo: Cultrix, 1968.

WILSON, Edward. A conquista social da Terra. São Paulo: Companhia das Letras, 2013.

Recebido em 28/09/2017.

Aprovado em 06/09/2018. 
